\title{
THE IMPACT OF SMARTPHONE USAGE IN ADOLESCENTS 15-24 YEARS OLD IN JABODETABEK REGION
}

\author{
Loveria Sekarrini \\ Study Programme of Public Health STIKes Bhakti Pertiwi Indonesia \\ Puri Alam Kencana 2, Blok O No.1, Nanggewer Mekar, Cibinong Bogor, Indonesia \\ Correspondence Address: Loveria Sekarrini \\ E-mail: loveria2012@gmail.com
}

\begin{abstract}
Youth and technology in the millennial era are inseparable. The need for technology makes smartphones the main needs that cannot be separated from the daily lives of youth. The use of smartphones has many benefits but not a few of its users experience addiction. Addiction on smartphones has different characteristics compared to other types of addiction. The aim of this study was to determine the description of smartphone addiction and the impact of physical, mental and sosial health in adolescents aged 10-24 years in Jabodetabek area. The research methodology used crosssectional study with online survey of 118 respondents and focus on the characteristics of respondents, average usage time, time spent playing smartphones when they wake up, the purpose of using smartphones, the most frequently applications used, the impact of smartphone use. The results showed that almost half of the respondents experienced smartphone addiction at a moderate level $(40.7 \%)$ and there were $16.9 \%$ who experienced severe addiction. The effects of smartphone addiction include problems with mild anxiety (45.8\%) and complaints of hands, neck and eyes. Most complaints were on eye health problems such as watery eyes (73.7\%), itching $(70.3 \%)$ and blurred vision $(66.1 \%)$. In addition, other complaints that many feel are in the hands such as tingling (67.8\%) and wrist pain (31.4\%). Excessive smartphone use has been shown to have an impact on physical health. For this reason, further research is needed to find out other health impacts both physically, mentally and sosially.
\end{abstract}

Keywords: Smartphone Addiction, Addiction, Musculosceletal Disorder

\section{ABSTRAK}

Remaja dan teknologi di era milenial ini menjadi hal yang tak terpisahkan. Kebutuhan akan teknologi menjadikan smartphone sebagai kebutuhan utama yang tidak lepas dari keseharian remaja. Penggunaan smartphone memiliki banyak manfaat namun tidak sedikit dari penggunanya yang mengalami adiksi. Adiksi pada smartphone memiliki karakterisitik yang berbeda dibandingkan dengan jenis adiksi lainnya. Tujuan dari penelitian ini adalah untuk mengetahui gambaran adiksi smartphone dan dampak kesehatan fisik, mental dan kesehatan sosial pada remaja usia 10-24 tahun di wilayah Jabodetabek. Metodologi penelitian yang digunakan adalah metode cross sectional dengan menggunakan online survey pada 118 responden tentang karakteristik responden, rata-rata waktu penggunaan, waktu yang dihabiskan untuk bermain smartphone saat bangun tidur, tujuan penggunaan smartphone, aplikasi yang paling sering digunakan, dampak penggunaan smartphone.

Hasil penelitian menunjukkan bahwa hampir separuh responden mengalami adiksi smartphone pada tingkat sedang (40,7\%) dan terdapat 16,9\% yang mengalami adiksi berat. Dampak dari adiksi smartphone diantaranya masalah anxiety ringan (45,8\%) dan keluhan pada tangan, leher, dan mata. Keluhan terbanyak berada pada masalah kesehatan mata seperti mata berair (73,7\%), terasa gatal $(70,3 \%)$ dan pandangan buram (66,1\%). Selain itu keluhan lain yang banyak dirasakan berada pada tangan seperti kemutan (67,8\%) dan sakit pada pergelangan tangan (31,4\%). Penggunaan smartphone yang berlebihan terbukti berdampak pada kesehatan fisik. Untuk itu, diperlukan penelitian lebih lanjut untuk mengetahui dampak kesehatan lainnya baik fisik, mental dan sosial.

Kata kunci: Adiksi Smartphone, Adiksi, Musculoskeletal Disorder

\section{INTRODUCTION}

Accelerating the development of a country is not separated from the presence of digital technology that is currently developing rapidly. Digital Report 2016 notes that Indonesia is the 30th sequence of 232 countries that always use internet. The average Internet usage that is accessed through a laptop or desktop in Indonesia is 4.7 hours per day, while access via mobile device as much as 3.5 hours per day. The use 
of social media in Indonesia also occupy a fairly high sequence of 27 from 232 countries that always use social media with an average of 2.9 hours per day. Indonesia currently has 88.1 million or $34 \%$ of active Internet users with primary use for social media as much as 79\%. (Martinez, 2016).

The use of internet especially through mobile device or smartphone can essentially help the community to be able to utilize the technology better. The rise of this internet usage makes the community dependent on technology in its daily life searching for reference, inspiration, entertainment to use in everyday life such as to order public transport, shopping, eating and many other activities are present to complement the needs of each community. This internet usage becomes a basic necessity so it will eventually have a positive and negative impact. One of the negative impacts that are not directly realized is the addiction to smartphones and not only to the social life, but also the health impact.

The addiction is defined as a condition for a person to give labor impact on physical and psychological health or to social life and an unbearable desire to do something repeatedly. Addiction can be interpreted as a state of being considered to initiate a constant desire to obtain a particular object and proceed constantly through that object as well as a constant state of wanting something (Karagün, E., Ekiz, Z.D., Sarper Kahveci, M, 2018).

According to A. Gurcan, S. Ozhan, R. Uslu in (Karagün, E., Ekiz, Z.D., Sarper Kahveci, M, 2018), the addiction to digital technology aimed at the loss of control over the excessive use of technology and the use of unlimited technology can cause serious adverse impacts for someone. Addiction to the internet and technology is defined as a state in which a person cannot eliminate it when a person cannot reach a technological product that causes a person to be in addiction. As a consequence of addiction to technology should really be considered and consider as the causes of the addiction such as impaired attention, hyperactivity, obesity, depression, and loneliness (Karagün, E., Ekiz, Z.D., Sarper Kahveci, M, 2018).

This situation occurs in many children and adolescents where adolescents experience physical and psychological problems when not using the technology. According to Hanafi, Siste, Wiguna, DKK (2019), in his research conducted in 185 medical students stated that labour behavior such as temperamenyal attitude has an association with the use of smartphones (OR 2,035, 95\% CI 1.119-3.701). This study shows that addiction to technology through smartphones has similarities to other types of behavioral addiction (Hanafi Enjeline, Siste Kristiana, Wiguna Tjhin, Kusumadewi Irmia, 2019).

This situation makes the youth who are the successor generation of the nation to be vulnerable to the health of both physical, psychological and social environments. Accelerated development of a country is not separated from the role of productive age especially teenagers. Currently, Indonesia is currently experiencing a demographic bonus that makes young people a potential group in advancing a country. Accelerating the development of a country can be improved through good resources and technology. Investing in a productive age group especially teenagers is very promising. Population census of 2010 records that there are 65 million teenagers in Indonesia, which means $28 \%$ of the total 238 million Indonesians are teenagers. Teenagers are more living in the urban area (28\%) Compared to rural areas (24\%). (UNFPA, 2014). The purpose of the study is to analyse smartphone addiction that impacts physical, mental and social health in adolescents aged 15-24 years in the Jabodetabek region. 


\section{METHODS}

This research is a descriptive study with cross sectional research design. The population used in this research is all ages 1524 years old who are in the Jabodetabek area, while the samples in this study are all aged 15-24 year old who fill out an online survey questionnaire related to the addiction and meet the criteria for inclusion and exclusion with the number of respondents as many as 118 respondents. The time of research and retrieval of data conducted in April-May 2019.

Variables used include the characteristics of respondents such as age, level of education, gender, bedtime), but also there are other supporting variables such as monthly money purchase, the cost of purchasing Internet quota and the amount of quota Spent for 1 month, residence, average usage time, time spent on playing smartphone while waking up, the purpose of smartphone usage, most used applications, impact of smartphone use.

Data and information that has been obtained through online surveys will then be analyzed using the analysis using univariate analysis by using computer application. Univariate analysis was conducted on this study to calculate the frequency distribution of each of the variables studied. The Data that has been analyzed will be presented in the form of tables or images and is narrated to facilitate the delivery of information about the research results.

\section{RESULT}

The results of the univariate analysis of the majority of respondents is $83.9 \%$ of the age range respondents ranging from 15-24 years and the average age of respondents is 20 years and the most age group is 20-24 years old. That is a number of $82.2 \%$. The most educational background is the educational background of DIV/S1 as much as $50.8 \%$. An overview of the respondent's characteristics are drawn in the following Table 1:

Table 1. Overview of respondents characteristics

\begin{tabular}{ccc}
\hline Variable & Amount & $\%$ \\
\hline \multicolumn{3}{c}{ Gender } \\
1. Males & 19 & 16.1 \\
2. Female & 99 & 83.9 \\
\hline Age & \\
1. 15-19 year & 21 & 17,8 \\
2. 20-24 year & 97 & 82,2 \\
\hline \multicolumn{3}{c}{ Last Education } \\
1. SMA & 46 \\
2. DIII & 12 & 39 \\
3. DIV/S1 & 60 & 50,2 \\
\hline
\end{tabular}

In this research, there were several other supporting variables depicting the characterisitics of respondents associated with smartphone use as to whether the use of a smartphone affects the time of the respondent's sleep, then the money Monthly, credit and internet purchase spending, quota spent on the internet, frequent providers used by teenagers, and average smartphone usage time Table 1.

Table 2. Supporting variables Overview

\begin{tabular}{lccccc}
\hline \multicolumn{1}{c}{ Variable } & Mean & Median & SD & Minimum & Maximum \\
\hline Bedtime & 6.69 & 6 & 1.84 & 2 & 18 \\
Monthly Snack Money & 997.881 & 900.000 & 580906.8 & 150.000 & 3.000 .000 \\
Internet Quota Fee & 82110 & 67500 & 59175.93 & 25.000 & 500.000 \\
Internet Quota (1 month) & 16.27 & 14.50 & 10.77 & 2 & 50 \\
Long use of smartphone (hours) & 10.2 & 10 & 4.25 & 2 & 22 \\
Long-wearing HP morning & 19.40 & 15 & 16.03 & 0 & 60 \\
(minutes) & & & & & \\
\hline
\end{tabular}


In Table 2 it appears that the average respondent has sufficient sleep time. In addition to that, the table is also the average monthly spending money of Rp. 997.881,which means the average daily money of teenagers from 15-24 years of age ranges from 30,000-40,000,-. This monthly allowance also reflects the quota used within 1 month. The average usage of Internet quota is $16,67 \mathrm{~GB}$ with an average length of smartphone usage in a day of 10.22 hours and long usage immediately after waking up for 19.40 minutes.

In figure 1 related to the use of the provider indicates that the provider is widely used for teenagers aged 15-24 years in the Jabodetabek region. The most widely used Provider is Tri (36\%) XL 20\% and Simpati as much as $19 \%$. The Provider Tri and XL are rated cheaper by teenagers and Simpati is judged better in terms of signal strength.

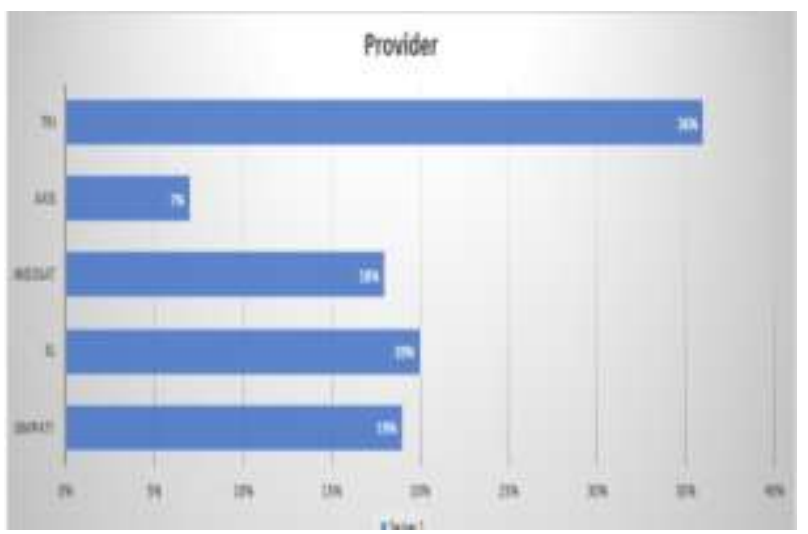

Figure 1. Distribution of provider usage This research is also an image that each teenager has varying habits in using smartphones. Most uses are used to use WhatsApps (93.2\%), the second highest use is to play online games that are as much as $76.3 \%$ and the third highest use is Instagram $(71.2 \%)$. A picture of the smartphone application is drawn in the following image 2:

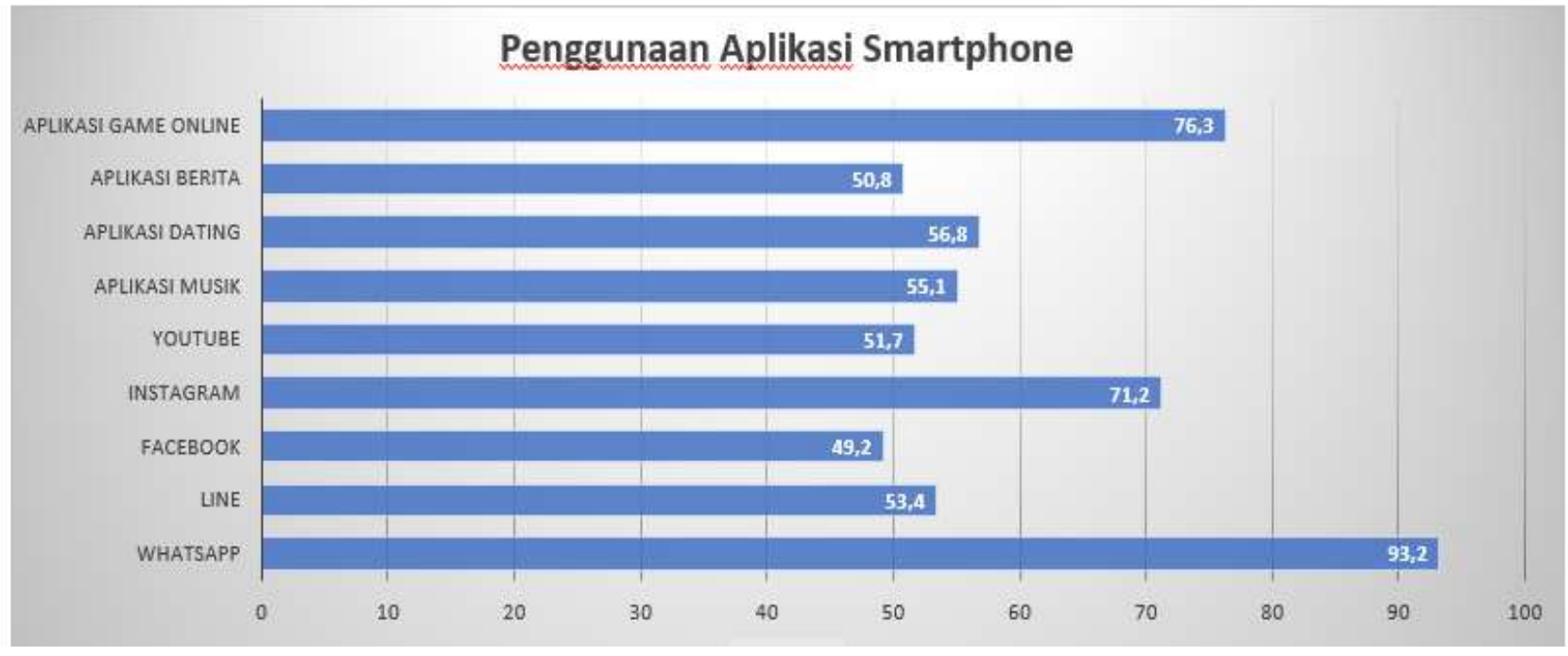

Figure 2. Smartphone Application Usage

After seeing smartphone usage habits, researchers learn more about the existing smartphone addiction in teenagers aged 1524 years. The image of the smartphone is listed as follows:
Table 3. Smartphone addiction in teens aged 15-24 years

\begin{tabular}{lcc}
\hline \multicolumn{1}{c}{$\begin{array}{c}\text { Smartphone } \\
\text { Addiction }\end{array}$} & Amount & \% \\
\hline 1. Never & 31 & 26,3 \\
2. Light weight & 19 & 16,1 \\
3. Moderate & 48 & 40,7 \\
4. Weight & 99 & 16,9 \\
\hline
\end{tabular}


Loveria Sekarrini, The Impact of Smartphone... 107

In Table 3, it was shown that nearly half of the respondents had smartphone addiction at moderate levels (40.7\%) And there were $16.9 \%$ of severe addiction. From 118 respondents there were $26.3 \%$ who did not experience the smartphone's addiction. This smartphone's addiction affects several

Table 4. Anxiety category in adolescents aged

\begin{tabular}{lcc}
\multicolumn{1}{c}{ 15-24 years } & & \\
\hline 1. Light weight & Amount & \% \\
2. Moderate & 54 & 45,8 \\
3. Weight & 34 & 28,8 \\
& 30 & 25,4 \\
\hline
\end{tabular}
problems both mentally, socially and in health. The problems that arise include the following:

Table 5. Anxiety in adolescents aged 15-24 years

\begin{tabular}{lcc}
\hline \multicolumn{1}{c}{ Statement } & Amount & \% \\
\hline I feel uncomfortable without access information from the phone & 37 & 31,4 \\
I was annoyed if I couldn't see the information from my phone when I wanted to see it & 40 & 33,9 \\
Running out of phone battery makes me panic & 29 & 24,6 \\
Running out of internet quota made me panic & 37 & 31,4 \\
When I can not check the phone, I have a feeling to immediately/always check it & 27 & 22,9 \\
I feel anxious not able to communicate quickly with family/friends & 50 & 42,4 \\
I'm worried my family and friends can't contact & 64 & 54,2 \\
I'm worried that I can't accept messages and calls & 27 & 22,9 \\
I am afraid of intensive communication with family and friends will be destroyed & 24 & 20,3 \\
I died in style because I could not check the notification on my phone & 56 & 47,5 \\
I die of style because I don't know how to do & 25 & 21,2 \\
I can not concentrate well in the classroom when using a smartphone & 26 & 22 \\
I have experience of blurred views when using excessive smartphones & 21 & 17,8 \\
I feel a mild headache when using excessive smartphones & 45 & 38,1 \\
I feel pain in my wrist when using my smartphone & 36 & 30,5 \\
I feel comfortable using a smartphone & 53 & 44,9 \\
I feel confident when using a smartphone & 44 & 37,3 \\
I can remove or reduce stress using a smartphone & 26 & 22 \\
I can't afford to survive without a smartphone & 16 & 13,6 \\
I feel impatient when I don't grip a smartphone & 24 & 20,3 \\
I feel annoyed if anyone bothered me using a smartphone & 39 & 33,1 \\
I feel sick or sad once like losing a friend when not getting using a smartphone & 11 & 9,3 \\
\hline
\end{tabular}

One of the mental health problems that arise on this study focuses on anxiety, fear, worry and anxiety. Many teenagers experience a sense of anxiety due to smartphone use. Half of the respondents had mild anxiety problems (45.8\%).

A sense of concern (anxiety) from the use of this smartphone has an impact on adolescent mental or psychological health. Not a few teenagers are annoyed/irritated if anyone is annoying using a smartphone $(33.1 \%)$, then panic if the quota is exhausted (31.4\%), upset if not able to access information (33.9\%), anxiety can not contact family and friends ( $54.2 \%)$, then feeling awkward because they can not check the notification on the phone $(47.5 \%)$ to a sense of not being able to survive without smartphones and other complaints. 
This can have an impact on the problem of confidence and social development of adolescents in the future. Fear of not being able to keep pace with the latest developments in social media and anxiety fear of losing social identity in cyberspace will affect the social life of teenagers. The descriptions ofdifferent types of anxiety experienced by adolescents can be seen in Table 5 below.

Table 6. Social life in teens aged 15-24 years

\begin{tabular}{lcc}
\hline \multicolumn{1}{c}{ Social life } & Amount & \% \\
\hline 1. Never & 57 & 48,3 \\
2. Light weight & 46 & 39 \\
3. Moderate & 14 & 11,9 \\
4. Weight & 1 & 0,8 \\
\hline
\end{tabular}

Many teenagers are unaware that smartphone addiction has an impact on social life. In
Table 6 , there were $48 \%$ of respondents who had no impact on the use of smartphones on their social life, but there were $11.9 \%$ and $0.8 \%$ who had problems in his social life. The impact of social life that appears on each teenager will certainly differ depending on the use of smartphones from each individual. The impact on this teen's social life has a mild to severe impact such as feeling closer to a friend in cyberspace, always checking the smartphone not to leave information and prefer to talk to friends on social media. In addition many teenagers also rely on smartphones for various things ranging from sharing what they feel, find the way, the media to relieve stress so that smartphones become a means for adolescents to depend in running all Including using a smartphone when driving is shot in Table 7 below:

Table 7. Social impact on adolescents aged 15-24 years

\begin{tabular}{lcc}
\hline \multicolumn{1}{c}{ Statement } & Amount & \% \\
\hline I'm uncomfortable with not being able to know the latest on social media and other & 24 & 20,3 \\
online information & 56 & 47,5 \\
I'm worried that I can not check Whatapps, line, or other social media & 25 & 21,2 \\
I felt my relationship with friends I knew via smartphones closer than my friends & & \\
around me & 12 & 10,2 \\
I feel sick or sad once like losing a friend when not getting using a smartphone & 11 & 9,3 \\
I feel friends on social media that I know through my smartphone more understand & & \\
me than with my friends & & \\
I always check my smartphone to prevent you from missing out on information on & & 41,5 \\
my social media & 49 & \\
I always check social media every waking sleep & & \\
I prefer to talk to a friend I know on social media compared to a friend around me & & \\
or my family & 28 & 23,7 \\
I would rather be searching or browsing than ask information to others & 24 & 20,3 \\
I said that I too much/often use a smartphone & 22 & 18,6 \\
I always open social media while learning & 42 & 35,6 \\
I always lay sambal opening social media & 23 & 19,5 \\
I always do my activities while using sosmed & \\
\hline
\end{tabular}




\begin{tabular}{lcc}
\hline \multicolumn{1}{c}{ Statement } & Amount & $\mathbf{\%}$ \\
\hline $\begin{array}{l}\text { I often open a smartphone when driving a car or a motorcycle to discuss } \\
\text { WhatsApp/Line/telegram/other social media or picking up telephone }\end{array}$ & 8 & 6,8 \\
\hline
\end{tabular}

In addition to the anxiety and social impacts that arise in adolescents, there are also a number of addiction symptoms that affect physical health. Table 8, showed that many teenagers experiencing various complaints ranging from complaints on the hands, neck, and eyes. The most complaints are on eye health issues such as watery eyes (73.7\%), itching (70.3\%) and blurred vision $(66.1 \%)$. In addition, other complaints that are widely perceived to be on hand such as tingling $(67.8 \%)$ and pain in the wrist $(31.4 \%)$.

Table 8. Health impacts on adolescents aged 15-24 years

\begin{tabular}{lcc}
\hline \multicolumn{1}{c}{ Health impacts } & Amount & \% \\
\hline Headaches & 67 & 56,8 \\
Wrist pain When using HP & 37 & 31,4 \\
Waking from sleep from pain in the wrist & 20 & 16,9 \\
Tingling when/after using HP & 80 & 67,8 \\
Tingling or numbness after moving the hand & 21 & 17,8 \\
Neck pain & & 26,3 \\
Watery eyes & 31 & 73,7 \\
Eye feeling tense & 87 & 49,2 \\
Painful eyes & 58 & 55,9 \\
Itchy eyes & 66 & 70,3 \\
Red-Eye & 83 & 41,5 \\
Blurred vision & 49 & 66,1 \\
Double Vision & 78 & 54,2 \\
\hline
\end{tabular}

\section{DISCUSSION}

The use of smartphones has a positive and negative impact. According to WHO, health is defined as a matter of physical, mental and social health so that if viewed from the definition it is image that excessive use of smartphones can affect mental health, social and health.

To find out more about the impact of smartphone usage, researchers are focusing on the types of applications commonly used by teenagers aged 15-24 years. The results of this research illustrate that chat applications such as WhatsApp (91.2\%) become an excellent app that becomes a major necessity of all smartphones. In addition to chat applications, online gaming applications $(76.3 \%)$ and social media $(71.2 \%)$ Like Instagram also become the main application needs.

This is in line with the research conducted in Pakistan in children aged 5-16 years where the most frequently used application is chat application ie WhatsApp and followed by the application of online 
games, music, videos and movies and cameras (Tariq, Tariq, Hussain, \& Shahid, 2018).

In addition to the impact on anxiety, there are still other impacts such as selfesteem and other mental health that impact social interactions or social health in adolescents. One of the problems that often arise is to prefer to talk to friends on social media compared to the environment $(41.5 \%)$, then the proximity of friends on social media is better compared to the surrounding environment $(21.2 \%)$ even to the extend of feeling anxiety and worry when does not have an existence in cyberspace. The existence of this virtual world can have an impact on adolescent self-esteem where teenagers should indirectly follow the developments on social media.

The thing that arises later is a matter of verbal violence where this type of emotional violence can cause fear of humiliation or demeaning. This will have an impact on social interactions and the usage of smartphone continuously improves stress especially in mental health and adolescent social interactions (Yun, Shim, \& Jeong, 2019).

The current smartphone is equipped with a touch screen that provides convenience for its users. The use of touch screens continuously and repetitive activities due to addiction can negatively impact the hand and cause musculoskeletal disorders. The results showed that there were some symptoms of musculoskeletal disorders in which there were $31.4 \%$ of teenagers who had pain in the wrist when using HP even had awakened from sleep due to illness in wrist as much as $16.9 \%$. In addition there are $67.8 \%$ that feel tingling when or after HP even have experienced numbness as much as $17.8 \%$. In addition to the upper hand or extremities, there are adolescents who have suffered a neck pain of $26.3 \%$.
Systematic review results related to these musculoskeletal symptoms indicate that the use of touch screen on another smartphone or portable device has a potential effect on physical health including the symptoms of musculoskeletal disorders. Systematic This review also shows that smartphone use can increase musculoskeletal stress on the neck compared to using a desktop computer and increase the stress on the wrist while using a smartphone Compared to using the phone keypad (Toh, Coenen, Howie, \& Straker, 2017).

The use of smartphone activities carried out for a long time or continuous activities will cause problems in muscles, joints and ligaments. In addition, eye health problems as well as other health problems such as mental and social can also affect the lives of teenagers.

\section{CONCLUSION}

It can be concluded that smartphone addiction is a new addiction that can have an impact on physical, mental and social health. Mental health problems become the most prominent to be resolved. It is suggested that the government and all related cross sectors to pay more attention to the problem os smartphone addiction as one form of addiction that needs to be alert.

Family participation, community and government should pay more attention to adolescents who experience smartphone addiction. They should increase public space and opportunity for teens to have more interaction in the real world. Another way, is to develop various programs to minimize addiction of smartphones. To find out the extent of the impct of smartphone addiction on health, further research is needed to describe in detail any variables which have a direct impact on smartphone addiction. 


\section{REFERENCE}

Karagün, E., Ekiz, Z.D., Sarper Kahveci, M., (2018). An Investigation on the Digital Addiction of the Students of Faculty of Sports of Kocaeli University" https://doi.org/10.1051/s hsconf/20184801057

Hanafi Enjeline, Siste Kristiana, Wiguna Tjhin, Kusumadewi Irmia, N. M. W. (2019). Authors' contribution.

Martinez, A. (2016). Digital in 2016 by We Are Sosial Singapore.

Tariq, K., Tariq, R., Hussain, A., \& Shahid, M. (2018). Smartphone Usage and its Applications among School going Children ( 5-16 Years ) in Lahore , Pakistan, 18(June), 52-58. https://doi.org/10.18311/jeoh/2018/200 17
Toh, S. H., Coenen, P., Howie, E. K., \& Straker, L. M. (2017). The associations of mobile touch screen device use with musculoskeletal symptoms and exposures: A systematic review, 1-23. https://doi.org/10.1371/journal.pone.01 81220

UNFPA. (2014). Indonesian youth.

Yun, J., Shim, G., \& Jeong, B. (2019). Verbal Abuse Related to Self- Esteem Damage and Unjust Blame Harms Mental Health and Sosial Interaction in College Population, (July 2018), 1-14. https://doi.org/10.1038/s41598-01942199-6 